\title{
Voices of Liberation: Songs and the Liberation Struggle in South Africa
}

\author{
Rachidi Molapo
}

University of Venda, RSA

Rmolapo@univen.ac.za

\section{Doi:10.5901/mjss.2014.v5n27p985}

\begin{abstract}
Many communities around the world have taken part in songs and dance or have witnessed roles played by songs. However, scholarly focus on such a field of study has been very limited. This study challenges for a new consideration of what songs are and the roles they play or played in contemporary society. Songs have been means of communication, education and importantly played important roles in the struggle against apartheid. When the apartheid regime became repressive by banning or exiling leaders, suppressing information, songs in vernacular or indigenous languages flourished in promoting resistance texts. These songs flourished like graffities in repressive environments. They were used as propaganda tools by the liberation movements and at the same time dealing with state propaganda. They were platforms of propaganda in a dialectical relationship with the state but also embodied other elements beyond these parameters. Songs have been fundamental instruments of resistance, heritage and history. This study looks at how South African activists used songs and the struggle against apartheid and the post-apartheid scenario. Focus will be on the pre-1960 period, exile and the post- apartheid dynamics. A qualitative research methodology has been useful for this study because of the human agency aspect.
\end{abstract}

Keywords: Apartheid (racial discrimination), Nkosi sikelel' i-Africa (Lord bless Africa), siyanqonqoza (knocking) umshini wami, ibhunu (white farmer), dubula (shoot), exile.

\section{Introduction}

Oral history and songs have not found favour in scholarly work in South African scholarship. Most of our historians have been largely influenced by the works of the German historian Von Ranke's emphasis on archival or written sources. According to HughTrevor-Roper, Africa did not have history because it was primitive and backward but the history of the European (Mazrui,1999:580-676). This has posed huge challenges to the history of communities with a non-literary culture as they were or are largely perceived not to have written history.

However, some historians have seen the value of oral history and songs. In his work on forced removals of the Makuleke people in the Phafuri triangle, Patrick Harries shows how the Makuleke people used songs against "removals, proletarianisation and ethnic mobilisation". (Harries,1987:111) While Leroy Vail and Landeg White's work shows the use of poetry and songs as medium through which the history of plantation workers in Mozambique was reconstructed (Vail, 1991:205). This also showed the sufferings and resistance of plantation workers. In Deborah James's study on the 'songs of the women migrants' shows how women from the former Lebowa homeland or what has become known as Limpopo Province today, women became urbanised like their male counterparts. (James, 1999) These women organised themselves into small support groups such as 'mogodišano' or "women kiba" clubs for survival and entertainment. (James, 1999:1) They joined music and dance groups and competed along local and regional basis. These songs are more "social" and "cultural" in orientation than "political" in nature.

In this study, songs capture the history and heritage of a people. Through these songs, we are able to see the educative aspects of songs as they are rooted in particular contexts. One song that started as a hymn has rich history in South Africa's struggle against 'racial rule'(Saunders: 2). White contact with Blacks saw missionaries from European countries coming into the country to civilise and introduce the native speakers to the word of God. One such a song that arose out of the missionary projects was from the Methodist church called Nkosi sikeleli' i-Africa.

Nkosi sikeleli' iafrica started as a hymn composed by Enoch Sontonga.(Sowetan, 2005). In 1925 the African National Congress (ANC) adopted the hymn as its anthem.

The song states:

Nkosi sikeleli' i-Africa Lord bless Africa

Maluphakanyisw' uphondo Iwayo Let its horn be blessed

Yiswa immitandazo yethu Listen also to our prayers 


\author{
Nkosi sikelela -Nkosi Sikelela Lord Bless \\ Maluphanyis' uphondo Iwayo Come spirit \\ Yizwa imitatandazo yethu Listen to our prayers \\ Nkosi sikelela-Thina Iusapho Iwayo We, thy children. \\ Nkosi sikelela \\ Thina Iusapho Iwayo \\ Morena boloka \\ Sechaba sa heso \\ O fedise dintwa le matswenyeho \\ Morena boloka \\ Sechaba sa heso.
}

The anthem was sung at functions where South Africans found themselves in exile and in South Africa. It is deeply religious reflecting the beliefs of the people on issues of justice and peace. Apart from the secular aspects of notions of justice, the hymn makes people aware of a higher deity to consider in human affairs. The hymn makes passionate plea to the higher deity for an end to suffering and poverty which are prevalent in the country. Other governments within Southern Africa such as Zambia, Tanzania, Zimbabwe have adopted this anthem as well.

After the banning of organisations in South Africa following the Sharpeville massacre, scores of activists left the country for exile while others were imprisoned. Thabo Mbeki, a young South African who left the country in the early 1960s, remembers that he and some of his colleagues sang,' onwards Christian soldiers'.

Reflecting on his detention experiences, Joe Slovo makes the point that:

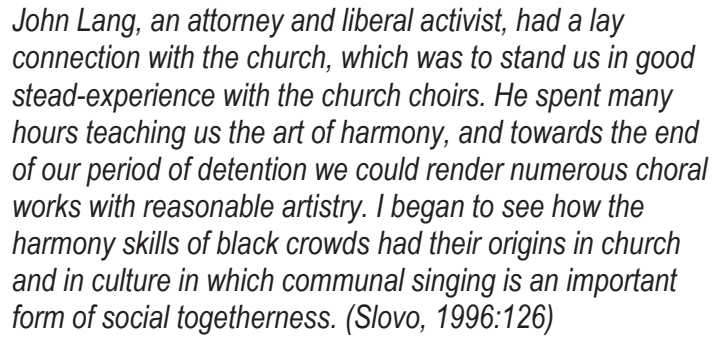

After the banning of the ANC and other organisations in 1960, the arrest of the MK High Command in 1963, the leadership of the organisations passed over to Oliver Tambo as leader of the external mission. The following song reflects that situation.

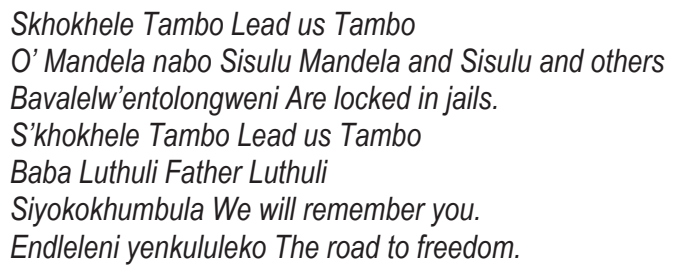

This song tells us a bit about the leadership changes within the liberation movement. The leadership of the organisation changed after the Rivonia arrest. Reginald Oliver Tambo took over. Supporters were singing this song to show sadness after Albert Luthuli, an ANC president from 1944-1967 was killed by a moving train in Natal. This generated suspicions on the government as he was banned and confined to his house in Groutville.

Between1960 to 1968 the internal resistance movement in the country was silent. The fear of long term imprisonment and exile inflicted so much fear in activists in showing any resistance to the state. The structures of the movement in the country were totally wiped out.

It was at the end of the 1960s that a group of students at the University of Natal ignited the resistance against 'racial order'. The students shared a different ideological orientation known as black consciousness movement (BCM) from the ANC which placed emphasis on liberating the oppressed mentally so that they would be in a position to challenge their oppressors. Steven Bantu Biko became famous for leading a breakaway student movement South African 
Student Organisation (SASO) from the white dominated National Union of South African Students (NUSAS). (Biko,1978:11)

The formation of SASO influenced student politics in the country and the majority of black leaders in the country articulated a black consciousness perspective. This was a powerful paradigm shift in the post- Sharpeville era in the absence of the ANC and the PAC with their ideologies. Ngugi wa Thiong'o, one of Africa's best writers articulated the role Biko and the movement he represented by stating that, "Biko is among this great gallery of people whose work and devotion have impacted those beyond the native shores and which make it possible for us even to talk about the possibilities of a new Africa out of the ashes of latter-day empires". (Ngugi wa Thiong'0, 2009: 51)

As these developments were taking place in the country those who left the country for exile struggled to return after acquiring military training. This saw groups from South Africa and Zimbabwe establishing a joint front to be able to challenge for power in their respective countries in terms of what became known as the Wankie campaign. These efforts were heroic but many of the cadres from the respective entities ended in jails in Zimbabwe and Botswana because they failed to penetrate the settler military establishments.

The tragic death of Chief Albert Luthuli coincided with the group of guerrillas who had attempted to cross into Zimbabwe and South Africa from Zambia. This campaign was named after Luthuli and became known as the Luthuli detachment. The schemes that ensued during this encounter had casualties from both sides.

The land question in both countries continued to cause bitterness within the exile communities and this is reflected in the kinds of songs sung. One song stated that:

\author{
Sikhalela izwe lakithi we mourn for our country. \\ Elathathwa ngamakalantshane which was taken by marauders. \\ WenamZulu, Mxhosa, Mosotho You Zulu, Xhosa, Sotho \\ Hlanganani Unite. (Mzamane, 1996:32)
}

The basis of the South African land question is rooted in colonial conquest. All Black independent states were brought under colonial control by the 1890s. In the middle of the1890s, Zimbabweans were dispossessed. While in South Africa after being defeated in the battlefields, the white parliament signed the Natives Land Act of 1913, which reserved $80 \%$ of the land to the whites while the black majority had to occupy $13 \%$ of the land. This has left a huge legacy of landlessness in the country.

The song has drawn heavily on Pixley ka Isaka Seme, the founder member of the ANC's historical call of 1912 for the natives to unite (Rive, 1991:9-10). For him Black unity was a central condition for the blacks to be able to challenge their oppression.

Another popular song sung by exiles was 'Thina Sizwe' (we the people).

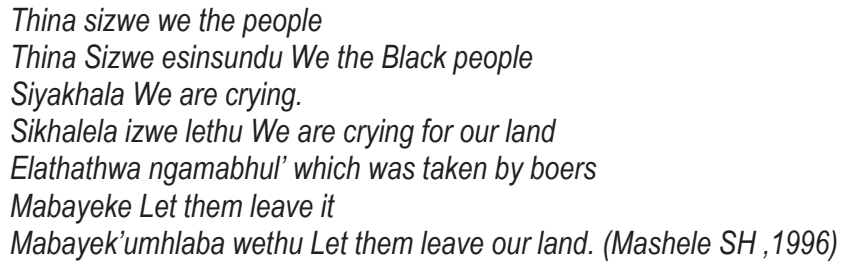

This song reflects the struggle for land in the country. The process of land dispossession was long and a protracted one. The wars of dispossession resulted in the white minority gaining control over the ownership of land in South Africa. The colonial state took an active part in this process with the provision of legislation such as the 1913 Land Act, 1936 land Act. There was an emotional attachment to the land as shown by the line "thina sizwe" (we the people) and 'sikhalela izwe lethu' (crying for our land).

However, the struggle against apartheid took a different turn from the late 1980s. The government was finding it difficult to operate as it used to do in the past. There were new demands on the table by the international community which needed South Africa to change its racial discriminatory legislations. Sanctions and boycotts were imposed upon the state. This proved costly for the government as it was isolated from the international community.

Nelson Mandela and his comrades in jails who had been forgotten because of the repressive state machinery resurfaced in the popular imagination. A song that captures the era states that:

Mandela says fight for freedom

Freedom is in your hands 


\author{
Mandela says freedom now. \\ Now we say away with slavery \\ In our land of Africa. \\ Rolihlahla Mandela \\ Freedom is in your hands \\ Show us the way \\ In our land of Africa. \\ Vula Botha siyanqonqoza \\ Khulul' uMandela asikhokhele \\ Open Botha, we are knocking \\ Release Mandela, so he can lead us \\ In all my trouble and suffering \\ Mandela is with me \\ Even amidst hippos \\ Mandela is with me \\ Amandla!
}

The 1980s represented a dramatic turn of events in South African political history. The exile movement that struggled to remove the apartheid state through military means was able to establish connections with the internal struggle. However, by the 1970s workers in Durban had launched some wildcat strikes demanding better working conditions and better wages. Demands for workers were largely work related but as time went on, community and national issues were articulated as part of the agenda.

By 1976, the students of Soweto clashed with the police over Afrikaans as a medium of instructions in their schools. This peaceful demonstration by students culminated in scores of students losing lives at the hands of the police. Since Sharpeville, South Africa was again in the international media showing how brutal apartheid was. Lives of black people were proving to be cheap as the perpetrators of these deaths never faced any legal consequence as a result of their actions.

When government tried to respond to political pressure by creating new houses for coloured and Indian representation known as tri-cameral parliament this led to the formation of the United Democratic Front resisting such. A campaign was established around Nelson Mandela as a unifying figure for the anti-apartheid struggle. This linked closely with the demands of the international community for political reforms in South Africa. Sanctions that were imposed on South Africa because of her racially discriminatory legislations had serious impact in the country.

By the 1980s government started secretive talks with Nelson Mandela in prison but these could not yield results as government was in serious crisis of legitimacy. Mandela could not renounce the ANC his organisation and its armed wing, Umkhonto we Sizwe and be confined to Transkei his place of birth as part of the homeland project.

The song says "vula Botha siyaqonqoza" (open Botha we are knocking). Botha refers to the president of the country, Mr P.W Botha, a military leader of the National Party. The president with his military background was taking the country on a confrontation path as he invaded the neighbouring states of Lesotho, Mozambique, Botswana and Zimbabwe in pursuit of ANC guerrillas. South Africa was the most highly militarised state in the whole of the region. Dulcie September an ANC representative in France was also killed by apartheid's secret agents. This situation brought condemnation of the South African government and further isolation.

The National Party replaced P. W Botha with Mr F.W De Klerk, the minister of education to take the country forward. This led to the release of political prisoners and the unbanning of organisations. In so doing, the government wanted to control the transition process in its own terms.

By the late 1980s, the country was gripped by violence of a political nature in particular around Natal and Johannesburg. This started as conflict between the UDF and Inkatha, a Zulu homeland and Natal based political party around political space.

The formation of the Convention for Democratic South Africa (CODESA) was a transitional forum before the 1994 general elections. The path to democracy was not smooth as serious political differences emerged between the National Party and the ANC over terms of the transition. The death of Chris Hani at the hands of right-wing white elements almost brought the country into a civil war. The massacre of innocent people at Boipatong all contributed to the mistrust of the government by the general public. As part of the transitional arrangements, the ANC had suspended "armed action" while the state intensified its low intensity conflict by using the military to destabilise communities.

To save the country from further bloodshed, 1994 was chosen as a year of the general elections which saw the ANC winning the elections. Nelson Mandela became the first president of the new South Africa but only served for one term. His deputy-Thabo Mbeki took over. When Mbeki's term of office was nearing an end, complications arose which led 
to Mr Jacob Zuma been suspended and removed from office as a deputy-president because of charges of rape, financial misappropriation.

Mbeki was seen as having orchestrated this complication by Zuma supporters. Whenever Zuma was appearing in court for his trial he would sing 'umshini wami', a metaphorical return to Mk.

The song said:

\author{
Umshini wami mshini wami my machine my machine \\ Khawuleth'umshini wami please bring my machine \\ Umshini wami mshini wami my machine my machine \\ Khawuleth'umshini wami please bring my machine \\ Umshini wami mshini wami my machine my machine \\ Khawuleth' umshini wami please bring my machine \\ Wen'uyang'imbambezela you are pulling me back \\ Umshini wami, khawuleth; umshini wami my machine, my \\ Machine.
}

The battle within the ANC for leadership of the party had created factions. The country was also affected by these internal divisions within the party. When Zuma was acquitted for rape, he looked destined for the presidency. The internal dynamics within the party saw Mbeki been recalled to Luthuli House 2 months before his term came to an end. A sizeable number of members of parliament resigned in indignation about how the matter was handled. Mr Kgalema Motlanthe was sworn in as an interim president.

Another song rooted in the apartheid era that brought controversies was "dubula ibhunu" (Afri-Forum and Julius Malema, 2010). Around 1994, Peter Mokaba, the late president of the ANC Youth League would inspire his followers to sing "kill the boer, kill the farmer" chant. As the country was in a transitional stage and reconciliation was regarded as part of national healing, he was reprimanded from singing the song. According to the song, "whites" represented the system of apartheid which included "boers" and "farmers".

Julius Malema the ANC Youth League president was inspired by his predecessor in the singing of the song but the wording was changed. It used vernacular language to mean the same thing. "dubula ibhunu" (shoot the white). AfriForum, a right-wing white grouping challenged this in the Equality Court as part of "hate speech" and the court ruled in favour of Afri-Forum and ordered Malema and his supporters not to chant the song anymore.

\title{
2. Conclusion
}

Songs play important roles in different societies. They are educational and can also be used in different contexts. Songs can be used as part of sources of information. It is therefore important to understand the meaning of words sang. As part of oral history, they need to be treated with caution like any other historical source.

Through these songs, some aspects of South African history can be learnt. But, this needs to be used in relations with other sources. Through these songs they gave us a sense of the different phases South Africa went through in its transition from apartheid to democracy.

Through these songs, one can also see the divisions and tensions within the society. These songs carry certain meanings that may not be appreciated by certain sections of the deeply divided society. These songs have emerged from the Christo-religious influences but assumed political dimensions the country was going through at that moment.

These songs also tell us about the liberation heritage the country has. These songs have been adapted to different context but their compositions have varied. As service delivery protests continue to be features of contemporary society, these songs have been adapted to the different regional dynamics.

\section{References}

Afri-Forum v Julius Malema, Equality Court case No: 20968/2010.

Biko Steve, I write what I like, (Johannesburg, Ravan Press, 1978)

Harries Patrick, A forgotten corner of the Transvaal Reconstructing the history of a relocated community through oral testimonies, in

Belinda Bozzoli (ed) Class, Community and Conflict: South African Perspectives, (Johannesburg, Ravan Press, 1987) Interview with Mr S.H Mashele for the songs 'Thina Sizwe'.

Rachidi Molapo, Challenges of the South African transition from apartheid to democracy, Freiburg, Germany 2-6 December 2013.

Rive Richard and Couzens Tim (ed) Seme the founder of the ANC, (Johannesburg, Skotaville and Mayibuye Books, 1991)

Slovo Joe, The Unfinished Autobiography, (Johannesburg, Ravan Press, 1996) 
Sowetan, April 19 2005, 'Sontonga honoured 100 years after his death'.

The Steve Biko Memorial Lectures 2000-2008, The Steve Biko Foundation and Macmillan, 2009.

Vail Leroil and Landeg White, Power and the Praise Poem, (London, James Currey, 1991)

Wikipedia.org/wiki/umshin-wami. 